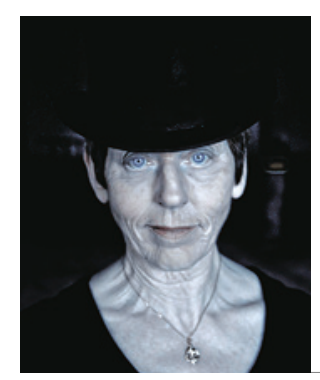

\title{
Målfrid Bolstad
}

Tidligere journalist

Foto: Nina Djærff

\section{Det jeg vil}

\section{Jeg vil ikke ha østrogen.}

Jeg vil ha fred.

Jeg vil sitte musestille i den gamle $\varnothing$ relappstolen og lefle meg i en lydløs stue og lukke øynene, lyttende etter meg - inne i meg selv - slik jeg var før lydene stjal meg og kastet meg for ungene, sjefene, kollegene, svigermor, sportsreporterne, hjem-is-bilen og telefonselgerne.

Jeg vil ikke være med på hyttetur til Hemsedal eller til Syden på sjanse, på kino eller bare ut en tur.

Jeg vil være i fred.

Jeg murer meg ikke inne. Nei, jeg lytter ikke til musikk. Nei, jeg skal ikke se på fjernsyn. Jeg hører ikke på radioen. Avisen ligger uhentet i postkassen. Jeg vil ikke følge med.

Jeg er i min egen myrullmyke fred.

\section{Jeg vil ikke ha østrogen.}

Jeg vil være sur.

I hele mitt liv har jeg lekt være-gladleken. Man må jo ta hensyn. Man må være blid og positiv - det smitter på andre. Man har jo ansvar for stemningen i familien og på jobben og overalt hvor stemning trengs.
Jeg vil ikke ha østrogen.

Jeg vil ha hetetokter.

Jeg vil sitte i stolen og la hetebølgene skylle gjennom kroppen. Deilig, tenker jeg, og minnes alle de timene jeg har frosset meg gjennom fotballkamper, håndballkamper, skirenn og korpsstevner. Eller iskalde hytter. Iblant trodde jeg at jeg aldri skulle bli varm igjen. Jeg priser varmen og tenker på hvor viselig naturen er innrettet. Så mange frysende timer i årelang tjeneste må selvsagt kompenseres før eller siden for at naturen skal være i balanse.

\section{Jeg vil ikke ha østrogen.}

Jeg vil ha tørre slimhinner.

Jeg vil ha slimhinner som er akkurat passe til en halvgammel dame som bare vil være i fred i godstolen.

\section{Jeg vil ikke ha østrogen.}

Jeg vil være deprimert.

Jeg vil grine hemningsløst til både b- og c-, ja, gjerne å-filmer for den saks skyld. Jeg vil snufse og sutre over all elendighet i verden og synes synd på alle og enhver og meg selv. Jeg vil grine øynene hemnings- løst ut av hodet mitt, så sørgelig som allting er. Det er snart en menneskealder siden kvinner fikk lov til å gråte. Likestilte kvinner gråter ikke. De tar gode eksamener og føder fire barn innimellom. Siden heiser de skuldrene og gjør karriere med tørre øyne. Fuktige øyne gir ikke samme status og karrieremuligheter.

Jeg vil ikke ha østrogen.

Jeg vil være trøtt.

Jeg vil ha lov til å hvile mine ben som har tråkket titusenvis av skritt, mine armer som har holdt og båret barn og bygningsmaterialer og strøket og løftet smått og stort titusener på titusener av ganger og mitt hjerte som har dunket i glede og angst for meg og mine, dag og natt, år etter år.

Jeg vil ikke ha østrogen.

Jeg vil ha fred.

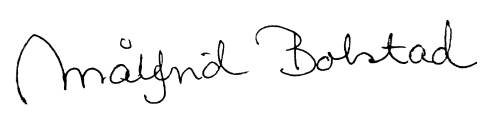

